\title{
The public responsibility of structured finance lawyers
}

Steven L. Schwarcz*

\section{Key points}

- Structured finance lawyers are increasingly being scrutinized when companies fail, but there is confusion as to the standards by which they should be judged.

- Society benefits where such lawyers are permitted to help facilitate matters in which neither the lawyer's actions nor the underlying transaction is, at the time, illegal as a matter of positive law. In these matters, the company's managers, not its structured finance counsel, should be responsible for ensuring that the company's investors are benefited, not harmed.

Lawyers, increasingly, are scrutinized as to their public responsibility when companies fail, particularly where the lawyer's involvement with the failed company is nontraditional and, arguably, intertwined with the failure. One of the least traditional roles of lawyers today is as counsel in structured finance transactions.

Companies originating these transactions (in that capacity, 'Originators') utilize special-purpose vehicles-SPVs, sometimes referred to interchangeably as specialpurpose entities or SPEs - to obtain various benefits. The use of SPVs introduces a complexity, however, that can confuse an Originator's investors. That, in turn, can raise doubt, if the Originator fails, whether the benefits were appropriate. This doubt is multiplied in debacles such as Enron and Parmalat, in which the failure of structured finance transactions arguably leads to the Originator's failure.

This article focuses on the public responsibility of lawyers who represent Originators of these transactions. The article proceeds by discussing structured finance, then by showing that the traditional view of a lawyer's public responsibility does little to inform the responsibility of structured finance lawyers and finally by examining de novo what that responsibility should be.

\section{Structured finance}

Structured finance transactions include securitization, project finance and similar transactions. In a securitization, for example, the Originator typically sells rights to payment from financial assets to a wholly owned SPV, which transfers these rights to an independent SPV, which in turn issues securities to capital market investors. ${ }^{1}$ The independent SPV uses the proceeds of the issuance to pay the first SPV for the financial

\footnotetext{
* Steven L. Schwarcz, Stanley A. Star Professor of Law \& Business, Duke University School of Law; Founding Director, Duke Global Capital Markets Center. This article is based in part on portions of the author's work, The Limits of Lawyering: Legal Opinions in Structured Finance, 84 Texas L. Rev. 1 (2005). Although the author is a consultant and possible expert witness in a case involving the public responsibility of structured finance lawyers, the views expressed in this article are entirely his own and intended to be impartial.

1 These investors should not be confused with investors in the Originator's securities.
} 
assets and the first SPV then uses those proceeds to pay the Originator. The investors, who are repaid from collections of the financial assets, buy the securities based on their assessments of the value of the financial assets. ${ }^{2}$

Structured finance transactions that are used to raise money off-balance-sheet have unquestioned benefits, such as better allocation of risk with assets. ${ }^{3}$ However, they also can mask liabilities that only first become evident when an Originator goes bankrupt. Say, for example, an Originator is able to account for a structured finance transaction as a sale with contingent recourse instead of balance-sheet debt. The contingent recourse then is likely to be disclosed only in footnotes to the Originator's balance sheet, not as a liability on the face of the balance sheet. ${ }^{4}$ Although diligent investors would learn of contingent recourse by reading those footnotes-'Post-Enron, no reasonable investor can claim ignorance of financial statement footnotes; investors have been widely educated to carefully review those footnotes as part of their investment or credit decisions ${ }^{5}$ investors who focus exclusively on the balance sheet itself without regard to risks disclosed in the footnotes would fail to anticipate that, in a bankruptcy, contingent recourse may be asserted as a claim against the Originator.

As counsel to Originators of structured finance transactions, lawyers act primarily if not exclusively as transactional counsel, helping to negotiate and document, issuing legal opinions concerning, and occasionally helping to structure, these transactions (rather than as securities law counsel, representing investors in or underwriters of securities issued by SPVs). In such capacity, lawyers typically issue two types of legal opinions. ${ }^{6}$ The first, a 'true sale' opinion, analyses whether transfers of financial assets from the Originator to the SPV constitutes a sale under applicable bankruptcy law or, instead, constitutes a loan from the SPV to the Originator secured by the financial assets. Achieving a true sale would isolate those financial assets in the SPV for the benefit of the SPV's investors, in the event the Originator later fails. The second legal opinion, a 'non-consolidation' opinion, analyses whether the Originator and the SPV would be substantively consolidated-effectively regarded as a single legal entity-for purposes of allocating the priority of claims against assets of these parties. ${ }^{7}$ Issuance of these

2 Steven L. Schwarcz, The Inherent Irrationality of Judgment Proofing, 52 Stan. L. Rev. 1, 6 (1999).

3 Steven L. Schwarcz, Enron and the Use and Abuse of Special Purpose Entities in Corporate Structures, 70 U. Cin. L. Rev. 1309, 1315 (2002).

4 In the United States, paras 8-13 of Financial Accounting Standard 5 ('FAS 5') require balance sheet disclosure of 'probable' contingent risks and footnote disclosure of risks that are not probable but nonetheless have a 'reasonable possibility' of occurring. Only remote risks may remain undisclosed.

5 Steven L. Schwarcz, Securitization Post-Enron, 25 Cardozo L. Rev. 1539, 1556 n.87 (2004).

6 Legal opinions are informed judgments, usually in writing, given by lawyers on issues of law. See Special Committee on Legal Opinions in Commercial Transactions et al., Legal Opinions to Third Parties: An Easier Path, 34 Bus. Law. 1891, 1896 (1979).

7 Steven L. Schwarcz, Structured Finance, a Guide to the Principles of Asset Securitization (3rd edn. \& supps. 2005), at §3:4, at 3-22; $\S 4: 1$, at $4-2 ; \S 4: 11$, at $4-38 ; \S 4: 12.3$, at $4-50$. 
opinions (collectively, 'structured finance opinions') helps assure investors and rating agencies $^{8}$ that the structure of the SPV transaction is 'bankruptcy remote."

Some have argued that by issuing structured finance opinions, lawyers should be uniquely responsible for the consequences of those opinions. ${ }^{10}$ That argument, though, ignores that an opining lawyer has no general duty to evaluate the business merits of the underlying transaction beyond the obvious ethical and legal obligations of not knowingly furthering a fraudulent transaction. ${ }^{11}$ Although the opining lawyer may be liable for negligence if his opinion is incorrect, this article assumes structured finance opinions that are technically correct. This assumption does not undermine the article's analysis or conclusions because only investors in the SPV's securities, who are the beneficiaries of these opinions, and not investors in the Originator's securities or other members of the public would be harmed by an incorrect opinion. ${ }^{12}$

This article also assumes that structured finance lawyers act without knowledge of, or intent to facilitate, a fraud. Where lawyers act with fraudulent intent, their responsibility is clear. ${ }^{13}$ On the other hand, there is nothing inherently deceptive or illegal about structured finance transactions. ${ }^{14}$

To help understand why a lawyer acting without negligence or fraudulent knowledge or intent should have a responsibility to the public, this article first examines the public responsibility of lawyers from a historical perspective.

\section{The historical perspective}

During the formative years of common law development, there was little if any real conflict between a lawyer's responsibility to a client and to the public, ${ }^{15}$ and thus little need to try to define that latter responsibility. The need to balance client and public responsibilities only became important in the United States after passage of the federal securities laws governing, among other things, the lawyer's role in preparing disclosure to investors of the risks associated with securities offerings. ${ }^{16}$ Shortly after these laws were enacted, one commentator predicted-in contrast to the traditional role of lawyers as zealous advocates of their clients-'a restatement of [the attorney's] answerability to the

8 See, eg Christopher Frost, Asset Securitization and Corporate Risk Allocation, 72 Tul. L. Rev. 101, 122 (1997). Rating agencies are private companies that assess or 'rate,' the risks associated with the full and timely payment of debt securities. Investors rely on the rating based on the rating agency's reputation.

9 For a discussion of 'bankruptcy remoteness,' see Structured Finance, n 8 above, $\S 3$.

10 See, eg In re Enron Corp. Sec., Derivative \& ERISA Litig., 235 F. Supp. 2d 549, 692 (S.D. Tex. 2002) (refusing to dismiss claims against a law firm when the complaint alleged, among other things, that the law firm issued true sale opinions necessary to effectuate the client's allegedly fraudulent plan).

11 Restatement (Third) of the Law Governing Lawyers $\$ 16 \mathrm{cmt}$. c (2000) ('A lawyer may not do or assist an unlawful act on behalf of a client...').

12 The Limits of Lawyering, $\mathrm{n} 1$ above.

13 See $\mathrm{n} 12$ above. See also In re Parmalat Securities Litigation, 383 F. Supp. 2 d 616 (S.D.N.Y. 2005).

14 Securitization Post-Enron, n 6 above, at 1551-74 (arguing that securitization, the dominant form of structured finance transaction, is efficient, fair, and economically desirable).

15 See, eg Marshall L. Small, An Attorney's Responsibilities Under Federal and State Securities Laws: Private Counselor or Public Servant?, 61 Cal. L. Rev. 1189, 1189 (1973).

16 These laws, codified at 15 USC $\$ \$ 77 a-78111$ (2005), primarily consist of the Securities Act of 1933, codified at 15 USC $\S \S 77 \mathrm{a}-77 \mathrm{bbbb}$ (2005), and the Securities Exchange Act of 1934, codified at 15 USC $\S \S 78 \mathrm{a}-78 \mathrm{~mm}$ (2005). 
court and to the society, and a reminder that he is not an ordinary employee of his client. $^{17}$ Others similarly observed that business pressures were blurring the line between a lawyer's duty to his client and his duty to the public. ${ }^{18}$ Until recently, however, the debate over a lawyer's responsibility to the public has been largely limited to the unique responsibility of securities lawyers. ${ }^{19}$ And, even in that limited context, much of the debate has focused on the technical jurisdictional issue under United States securities law of whether lawyers, as aiders and abettors rather than primary securities law violators, are even subject to suit under the securities laws. ${ }^{20}$

Enron, WorldCom, Parmalat and similar debacles have now increased the importance of the debate over a lawyer's public responsibilities and have expanded the debate's scope beyond that of securities lawyers. Structured finance lawyers are now being criticized in their primary role as transactional counsel, as opposed to in their occasional role as securities law counsel to the SPV issuing securities. The historical debate provides little guidance for assessing the public responsibility of structured finance lawyers in that primary role.

\section{What should be the public responsibility of structured finance lawyers?}

Because the public responsibility of structured finance lawyers neither turns on traditional factors, such as fraud or negligence, nor is governed by securities laws, ${ }^{21}$ this article examines that responsibility from a normative standpoint. Many terms, some with overlapping meanings, are used to describe why government imposes responsibility on private parties. Scholars talk about increasing social welfare, ${ }^{22}$ addressing the 'tragedy of the commons, ${ }^{23}$ reallocating benefits and achieving allocative fairness, ${ }^{24}$ maintaining norms and morals, ${ }^{25}$ preserving and enhancing the efficiency of markets, ${ }^{26}$ protecting parties from their own actions (paternalism) ${ }^{27}$ and protecting parties from externalities. ${ }^{28}$

17 Nathan Isaacs, Liability of the Lawyer for Bad Advice, 24 Cal. L. Rev. 39, 47 (1935).

18 See, eg Harlan F. Stone, The Public Influence of the Bar, 48 Harv. L. Rev. 1, 7 (1934); Robert T. Swaine, Big Impact of Business on the Profession: An Answer to Critics of the Modern Bar, 35 ABA J. 89, 171 (1949).

19 In November 2005, the Texas Law Review published an issue (84 Tex. L. Rev. 1 et seq.) largely dedicated to the public responsibility of lawyers issuing structured finance opinions.

20 The Limits of Lawyering, $\mathrm{n} 1$ above, at 16.

21 But Cf The Limits of Lawyering, $\mathrm{n} 1$ above, at 46 and 47 (discussing the possible implications to structured finance lawyers of SEC Rule 13b2-2 promulgated pursuant to $\S 303$ of the Sarbanes-Oxley Act).

22 See, eg Louis Kaplow \& Steven Shavell, Fairness Versus Welfare, 114 Harv. L. Rev. 961, 967 (2001); Richard A. Posner, Economic Analysis of Law 25 (6th edn, 2003).

23 Garrett Hardin, The Tragedy of the Commons, 162 Science 1243 (1968) (defining a tragedy of the commons as several independent persons all using a common and diminishable resource where their aggregate use threatens the sustainability of that resource).

24 Kaplow and Shavell, n 23 above, at 999-1004.

25 See, eg Suzanne B. Goldberg, Morals-Based Justifications For Lawmaking: Before and After Lawrence v Texas, 88 Minn. L. Rev. 1233, 1243-58 (2004).

26 Posner, n 23 above, at 457.

27 See, eg Thaddeus Mason Pope, Counting the Dragon's Teeth and Claws: The Definition of Hard Paternalism, 20 Ga. St. U. L. Rev. 659, 660 (2004).

28 See, eg Alan Stone, Regulation and Its Alternatives 91, 91-123 (1982) ('examining the concept of externalities, which may be defined as an activity that imposes costs or benefits upon persons who are not parties to a transaction or contract'). 
Most of these reasons for imposing responsibility do not appear to apply to the actions of structured finance lawyers. Except to the extent already bound up with 'market efficiency' or 'externalities', their actions are unlikely to impact social welfare, problems of the 'commons', allocative fairness, morals, or norms. Paternalism also should not be a basis for imposing responsibility because structured finance lawyers invariably act in a sophisticated business and finance context.

Although market efficiency clearly applies to the actions of structured finance lawyers, it should not justify imposing responsibility to the extent those actions help to facilitate efficient structured finance transactions. Most structured finance transactions are not only efficient, ${ }^{29}$ but also the opinions issued to facilitate these transactions do so in an efficient way-by targeting the elements of information asymmetry of concern to investors. $^{30}$

The principal basis for government to impose responsibility on structured finance lawyers is therefore to protect against externalities. Because it is irrelevant to this article's analysis of whether such responsibility is imposed through law per se or through ethical rules, the term 'lawful' is used to refer to externalities whose causation is neither illegal nor formally unethical (the term 'unlawful' conversely meaning externalities whose causation is either illegal or formally unethical).

To what extent should responsibility be imposed on structured finance lawyers to help avoid externalities? In answering this question, one must distinguish the role of structured finance lawyers from the traditional role of lawyers as advocates. ${ }^{31}$ Although the externalities caused by traditional lawyering — which focuses on courtroom and client advocacy in an adversary system-have been extensively studied, ${ }^{32}$ that scholarship is mostly inapplicable to the responsibility of structured finance lawyers; their externalities are only beginning to be studied. ${ }^{33}$

To aid that study, it is useful to divide externalities into two categories: lawful externalities and unlawful externalities. All transactions, including structured finance transactions, create externalities. ${ }^{34}$ Therefore, structured finance lawyers help to create externalities by facilitating such transactions. However, the paradigm of social ordering is that, left to independent bargaining, parties work out arrangements that-except to the extent the arrangements create externalities that society defines as unlawful ${ }^{35}$ - benefit the

\footnotetext{
29 See $\mathrm{n} 15$ above.

30 The Limits of Lawyering, $\mathrm{n} 1$ above, at 24 n. 125.

31 Cf. Model Code of Prof'l Responsibility EC 7-3, EC 7-4 (1969) (distinguishing between a lawyer's role as advocate and counselor).

32 See, eg Robert P. Burns, Professional Responsibility in the Trial Court, 44 S. Tex. L. Rev. 81, 109-10 (2002).

33 See The Limits of Lawyering, $\mathrm{n} 1$ above.

34 Cf Stone, n 29 above, at 97.

35 In a business context, the primary limitation on the social-ordering paradigm is that the arrangements should not create externalities that society defines as unlawful. Lawyers specifically help in this regard by advising clients on whether their arrangements are lawful.
} 
overall public good. ${ }^{36}$ To the extent the lawyers facilitate these arrangements, they are working to enhance the public good. ${ }^{37}$

Structured finance lawyers therefore should have the right to help facilitate lawful structured finance transactions. If they were constrained from doing so merely because these transactions cause externalities, structured finance lawyers would be forced to substitute their judgment about externalities for that of their clients. From an information standpoint, however, clients generally have more and better information about the consequences of a transaction other than the transaction's legality, and therefore are better positioned to make business decisions. Making structured finance lawyers responsible to second-guess their clients' business decisions would be inefficient, especially since "[v]aguely defined duties to "the public" threaten to increase the agency costs of the legal representation as lawyers may seek to pursue their own ideological goals in favour of client interests. ${ }^{38}$ Structured finance lawyers, who are specialists only in law, also would be ill-trained to assess and weigh the costs (including externalities) and benefits of their transactions. ${ }^{39}$ This insight helps explain US Congressional testimony on the role of transactional lawyers:

If a transaction is not illegal and has been approved by the appropriate levels of corporation's management, lawyers... may appropriately provide the requisite legal advice and opinions about legal issues relating to the transactions $[s i c]$. In doing so, the lawyers are not approving of the business decisions that were made by their clients. ${ }^{40}$

The social-ordering paradigm would be undermined, nonetheless, to the extent expert advisors, such as lawyers, provide inaccurate information that distorts transactional arrangements. This distortion could be especially significant in a structured finance transaction context, where legal opinions issued by structured finance lawyers are such a vital part of the information flow. And, admittedly, sometimes there is an information failure when structured finance transactions mask liabilities that first become evident only when an Originator goes bankrupt. ${ }^{41}$

This information failure, however, is generally not the result of inaccurate information provided by structured finance lawyers but the occasional investor failure to understand, much less appreciate, underlying disclosure concerning structured finance transactions. ${ }^{42}$ This failure can occur for at least two reasons. One is that investors-even sophisticated investors-do not always carefully review the disclosure, focusing

36 See, eg Adam Smith, An Inquiry Into the Nature and Causes of the Wealth of Nations 291-92, 547-48 n 292 (Kathryn Sutherland ed., Oxford University Press 1993) (1776); Michel Rosenfeld, Contract and Justice: The Relationship Between Classical Contract Law and Social Contract Theory, 70 Iowa L. Rev. 769, 847 (1985).

37 Cf generally Ronald J. Gilson, Value Creation by Business Lawyers: Legal Skills and Asset Pricing, 94 Yale L.J. 239 (1984).

38 Sean J. Griffith, Afterward and Comment: Towards an Ethical Duty to Market Investors, 35 Conn. L. Rev. 1223, 1234 n 43 (2003). 39 Cf The Limits of Lawyering, $\mathrm{n} 1$ above, at 29 (asking, for example, how counsel could balance costs and benefits where the resulting transaction creates a more efficient business but, in the process, costs a thousand jobs, impoverishes a community and destroys families).

40 The Financial Collapse of Enron-Part 4: Hearing Before the Subcomm. on Oversight and Investigations of the H. Comm. on Energy and Commerce, 107th Cong. 20 (2002) (statement of Joseph C. Dilg, Managing Partner, Vinson \& Elkins).

41 See n 4-6 above and accompanying text.

42 See n 5-6 above and accompanying text. 
exclusively on the Originator's balance sheet without regard to contingent risks disclosed in the footnotes and offering documents. ${ }^{43}$ Although some investors might fail to focus on these risks due to laziness, the more likely explanation for the failure is a fundamental lack of comprehension that these risks can be significant, resulting from a misunderstanding of the necessary and significant role of contingent recourse in structured finance transactions.

Because of information asymmetries between the Originator and the SPV's investors regarding transferred financial assets, investors always must demand, to the extent consistent with a true sale, some amount of contingent recourse against the Originator ${ }^{44}$ as a necessary solution to the problem of quality uncertainty. ${ }^{45}$ Law and accounting standards require that this recourse be disclosed. ${ }^{46}$ However, because investors are most familiar with ordinary sales of tangible assets, in which contingent recourse is typically limited to standard warranties, they do not always comprehend that a sale might expose the Originator to this greater level of contingent recourse. The solution to this failure is to educate investors to carefully read and understand the disclosure of contingent recourse, a task that is already beginning. ${ }^{47}$

Another reason why investors sometimes fail to understand and appreciate underlying disclosure is that some structured finance transactions are so complex that disclosure is necessarily imperfect-either oversimplifying the transaction or providing detail and intricacy beyond the comprehension level of even the most sophisticated investors and securities analysts. ${ }^{48}$ For these complex transactions, investors can be protected by requiring, in addition to otherwise applicable disclosure, that management of the Originator avoid material conflicts regarding those complex transactions. ${ }^{49}$

Thus, the real information failure in structured finance transactions is unrelated to the actions of structured finance lawyers, and has solutions that are likewise unrelated. That information failure therefore should not affect this article's reliance on the social ordering paradigm. ${ }^{50}$ Accordingly, where structured finance lawyers facilitate lawful transactions that create problematic externalities, the focus should not be on lawyer conduct but instead on whether to legally prohibit or otherwise limit those transactions.

Applying this framework, however, requires the resolution of two practical questions: in assessing lawfulness, should structured finance lawyers examine the entire transaction

43 Ibid.

44 See, eg Peter C. Pantaleo et al., Rethinking the Role of Recourse in the Sale of Financial Assets, 52 Bus. Law. 159, 163 (1996). 45 George A. Akerlof, The Market for 'Lemons': Quality Uncertainty and the Market Mechanism, 84 Q.J. Econ. 488, 499 (1970). Although Akerlof suggested other potential solutions to the problem of quality uncertainty, only the guarantee, or recourse, solution applies to the fact scenario of this article.

46 See $\mathrm{n} 5$ above and accompanying text.

47 See $\mathrm{n} 6$ above and accompanying text. Ascertaining the amount of contingent recourse and the likelihood that it will be asserted is not, however, a trivial task. See The Limits of Lawyering, n 1 above, at $31 \mathrm{n} 165$.

48 Steven L. Schwarcz, Rethinking the Disclosure Paradigm in a World of Complexity, 2004 U. Illinois L. Rev. 1 (2004).

49 Ibid. at 31-32, 35-36.

50 See n 36-38 above and accompanying text. 
or just the portion thereof relating to their specific tasks; and what should lawfulness mean in a world of changing norms? In a perfect universe, lawyers should examine the entire transaction, because doing so would be costless. Pragmatically, though, the scope of a structured finance lawyer's engagement may be more limited. ${ }^{51}$ If so, that lawyer would not be expected to assess the transaction's overall legality and certainly would not be paid for work performed in making that assessment. ${ }^{52}$

In this scenario, there are at least two practical ways to curtail externalities without requiring counsel to analyse the entire transaction for lawfulness. One approach is to permit counsel to assume legality if the tasks they perform are lawful and, in the course of performing those tasks, they do not spot warning signs putting them on notice of problems. Where, however, they do spot warning signs, they should investigate further to see if the warning sign, which may well be ambiguous, can be dispelled. ${ }^{53}$ If the warning sign cannot be dispelled or if other warning signs emerge, the lawyer should consider withdrawing from the representation. ${ }^{54}$ Whether the lawyer also should have some duty to inform government regulators is beyond the scope of this article.

It would be too limiting for this article, in a vacuum of fact, to attempt to define what constitutes warning signs. Because warning signs are more easily recognized than defined, the definition should develop on a case-by-case basis. ${ }^{55}$ Thus, a refusal by in-house counsel to issue a requested no-violation-of-law opinion should constitute a warning sign, ${ }^{56}$ as should a request that structured finance counsel make incorrect assumptions in opinions ${ }^{57}$ or the discovery of undisclosed side agreements. ${ }^{58} \mathrm{~A}$ transaction that is structured in disregard of current norms likewise might raise a warning sign. ${ }^{59}$ Although failure to see a business purpose in a structured finance transaction also might be a warning sign, ${ }^{60}$ that devolves on what constitutes a business purpose. Raising financing or reducing its cost should always be a good business purpose as should shifting risk on assets to outside investors or diversifying a company's funding sources. Mitigating taxes often has been viewed, in the United States, as a legitimate business purpose. ${ }^{61}$ Atleast until recently, it even could be argued that achieving an accounting treatment

51 The Limits of Lawyering, n 1 above, at 33-34 (observing that as companies bring more and more of their day-to-day work in-house, it is increasingly likely that outside law firms will work on only limited aspects of transactions).

52 The Limits of Lawyering, $\mathrm{n} 1$ above, at 33.

53 This approach is suggested ibid. at 34-35; Small, An Attorney's Responsibilities Under Federal and State Securities Laws, n 16 above, at 1199 .

54 The Limits of Lawyering, $\mathrm{n} 1$ above, at 34.

55 This approach follows the judicial litmus test of 'I know it when I see it.' Jacobellis v Ohio, 378 US 184, 197 (1964) (Stewart, J., concurring).

$56 \mathrm{n} 64$ below and accompanying text.

57 Cf United States v Simon, 425 F.2d 796, 806 (2nd Cir, 1969).

58 See, eg Report of Investigation by the Special Investigative Comm. of the Board of Directors of Enron Corp. 41-42, 49-50, 52 (1 February 2002).

59 n 69 below and accompanying text.

60 See, eg Richard Acello, Enron Lawyers in the Hot Seat, 90 ABA J 22, 23 (June 2004) (“'If a lawyer can't come up with a good business reason for what she is doing, the lesson [of Enron] is to think twice about it." (quoting Shaun Martin, legal ethics professor at University of San Diego)).

61 Chamberlin v Commissioner, 207 F.2d 462, 468, 470-71 (6th Cir, 1953). 
permitted by generally accepted accounting principles (GAAP) is itself a legitimate business purpose. ${ }^{62}$

Courts should also exercise caution against finding warning signs where none exist. For example, the fact that a structured finance transaction has loan-like economics should not itself constitute a warning sign because although 'in form, securitization [and other structured finance] transactions are contractually arranged sales of financial assets, [i]n economic substance... they are not dissimilar to transfers intended as security (i.e., loans secured by the financial assets). ${ }^{63}$ Structured finance lawyers, on the other hand, need to be cognizant of the reality that actions judged with the benefit of hindsight often suffer a psychological bias - the human tendency to exaggerate the extent to which a problem could have been anticipated. ${ }^{64}$ They therefore should give serious consideration to potential warning signs.

A second practical way to curtail externalities without requiring structured finance counsel to analyse the entire transaction for lawfulness is to additionally require structured finance counsel to obtain in appropriate cases, as part of their due diligence, an opinion from in-house counsel to the Originator that the overall structured finance transaction does not violate law (a 'no-violation-of-law' opinion). This approach not only takes into account the typically lower cost of in-house counsel but also recognizes the fundamental distinction between monitoring transactional lawfulness, meaning whether the transaction itself is intrinsically lawful, and monitoring corporate lawfulness, meaning whether the transaction would be lawful if engaged in by the particular clientcompany. A transaction can be lawful on its face but unlawful if engaged in by that company. Because in-house counsel have, or at least have access to, full information of the Originator, they can more effectively monitor corporate lawfulness.

This article is agnostic as to whether a no-violation-of-law opinion always should be required, since such an opinion could be costly ${ }^{65}$ and would not be a panacea. ${ }^{66}$ Imposing such a requirement would also be inconsistent to some extent with the existing norm that companies generally have no obligation to retain counsel when engaging in business transactions.

After the question of whether structured finance lawyers should examine the entire transaction or just the portion thereof relating to their specific tasks, the second question

62 A recent SEC staff report criticizes that business purpose. See Report and Recommendations Pursuant to Section 401(c) of the Sarbanes-Oxley Act of 2002 On Arrangements with Off-Balance Sheet Implications, Special Purpose Entities, and Transparency of Filings by Issuers (15 June 2005), available at http://www.sec.gov/news/studies/soxoffbalancerpt.pdf. But cf Use and Abuse of Special Purpose Entities, n 4 above, at 1315.

63 Steven L. Schwarcz, Collapsing Corporate Structures: Resolving the Tension Between Form and Substance, 60 Bus. Law. 109, 115 (2004).

64 Baruch Fischhoff, For Those Condemned To Study the Past: Heuristics and Biases in Hindsight, in Judgment Under Uncertainty: Heuristics and Biases 335, 341 (Daniel Kahneman et al. eds, 1982).

65 Scott Fitz Gibbon and Donald W. Glazer, Fitz Gibbon and Glazer on Legal Opinions § 13.2.1, at 429 (1992) (noting that issuing a no-violation-of-law opinion covering all laws could take 'weeks of work by a team of lawyers').

66 At least under customary practice today in the United States (as codified in American Bar Association guidelines), noviolation-of-law opinions are viewed as covering only 'law ... that, given the nature of the transaction and the parties to it, a lawyer in the relevant jurisdiction exercising customary diligence would reasonably recognize as being applicable.' TriBar Opinion Committee, Third-Party 'Closing' Opinions, 53 Bus. Law. 591, 662 (1998). 
that must be answered in order practically to apply this article's framework is: what should lawfulness mean in a world of changing norms? Irrespective of the approach selected, transactions that are lawful today sometimes might be suspect tomorrow. What should lawfulness mean in a world of changing laws and norms?

Lawfulness ultimately derives from a society's norms, and norms change in response to changing conditions. Where positive law reflects existing norms, lawfulness should be clear. But where there are disconnects between positive law and norms or disconnects between the positive law applicable at the time of a transaction and the time of its adjudication (ie disconnects over time), lawfulness may be ambiguous.

Disconnects between positive law and norms can occur in one of two ways. At the time of a structured finance transaction, the transaction (or portion thereof that should be examined) might comply with either positive law but not norms, or norms but not positive law. In the first case, structured finance lawyers theoretically should have the right to help facilitate the transaction since lawyers (and indeed transaction parties) must rely on objective standards, and the existence of positive law is such a standard. ${ }^{67}$ Norms, in contrast, represent what the law should be, which is often unsettled if not controversial.

In practice, though, helping to facilitate structured finance transactions that violate norms is risky, potentially leading to reputational loss and tempting judges, where the public suffers losses, to impose liability. Lawyers are especially at risk if they are the only remaining deep pockets. ${ }^{68}$ For these reasons, a transaction that is structured in disregard of current norms might well raise warning signs.

Turning now to disconnects over time, a structured finance transaction may initially comply with positive law; but positive law changes some time after the closing (hereinafter, ex post positive law) to make the transaction unlawful. Although structured finance counsel should have the right to help facilitate such transactions, some precedents are troubling, especially where ex post positive law is viewed as retroactive. Conceptually, this is most likely to occur (though not limited to situations) when there is a retrospective disconnect between positive law and norms, so that ex post positive law reflects ex ante norms. ${ }^{69}$ Unlike retroactive criminal laws, which (at least in the United States and the European Union) are invalid, ${ }^{70}$ retroactive non-criminal law is often upheld, even under international legal principles, so long as the retroactive law is non-discriminatory. ${ }^{71}$ Retroactivity can be implicit or explicit, although the former has no clear legal basis.

The practical problem with retroactive law, of course, is that parties violating it cannot know, at the time of their action, of the violation. Even when parties sense they may be

67 William Ewald, Comparative Jurisprudence (I): What Was it Like to Try a Rat?, 143 U Pa L Rev. 1889, 2123 (1995). 68 See, eg Nathan Koppel, Partial Protection-Plaintiffs Face a Supreme Court Barrier When Suing Law Firms for Fraud, Am Law, July 2004, at 77 .

69 Harold J. Krent, The Puzzling Boundary Between Criminal and Civil Retroactive Lawmaking, 84 Geo LJ 2143, 2158 (1996).

70 Calder v Bull, 3 US 386, 389-91 (1798). They also generally violate section 1, Article 7, of the European Convention on Human Rights.

71 See, eg Landgraf v USI Film Prods., 511 US 244, 267 (1994). 
violating norms, that is not per se unlawful. In a business and financial context, if not in other contexts, retroactive laws thus undermine the certainty and objectivity needed to structure transactions. ${ }^{72}$ Moreover, where the retroactive law concerns a politically sensitive topic there is potential for abuse. ${ }^{73}$ Because of this potential for abuse and the lack of certainty and objectivity needed to structure business and financial transactions, retroactivity should be frowned on and certainly should not be used as a basis to impose liability.

\section{Framework and applications}

The foregoing analysis yields the following framework. Structured finance lawyers should have the right to help facilitate lawful structured finance transactions, meaning those in which neither the lawyer's actions nor, to the extent set forth below, the transaction is then illegal as a matter of positive law. Where the transaction is lawful as a matter of positive law but nonetheless may violate norms, the structured finance lawyer may want to exercise special caution. ${ }^{74}$ In assessing whether a transaction is lawful, the structured finance lawyer should examine at least the portion of the transaction relating to the tasks performed. If in the course of that examination the lawyer spots warning signs, the lawyer should investigate further. What constitutes a warning sign should be decided by courts on a case-by-case basis because warning signs are more easily recognized than defined. In appropriate cases, the lawyer may want to obtain, as part of the due diligence investigation, an opinion from in-house counsel stating that the overall transaction does not violate law. Failure of in-house counsel to render such an opinion would signal a problem.

In the post-Enron regulatory environment, scholars have vigorously criticized the conduct of structured finance lawyers. ${ }^{75}$ That scholarship, however, does not generally propose actual legal constraints on, but merely aspirational goals for, such conduct. ${ }^{76}$ And where the scholarship does propose legal constraints, they are often impractical ${ }^{77}$ and not demonstrably preferable to this article's framework, which, by following the social ordering paradigm, should achieve an optimal public outcome overall.

An examination of some hypothetical situations illustrates the framework's application.

\section{Applying the framework}

Consider first how this article's framework would apply to a structured finance lawyer who helps facilitate a lawful structured finance transaction, which subsequently collapses

72 See, eg George Clemon Freeman, Jr, A Public Policy Essay: Superfund Retroactivity Revisited, 50 Bus Law 663, 682-83 (1995).

73 The Limits of Lawyering, $\mathrm{n} 1$ above, at 40-41.

$74 \mathrm{n} 69$ above and following text.

75 See, eg Griffith, Afterward and Comment: Towards an Ethical Duty to Market Investors, n 39 above, at 1252.

76 Richard W. Painter, The Moral Interdependence of Corporate Lawyers and Their Clients, 67 S Cal L Rev 507, 511-18 (arguing that, at least as a moral matter, lawyers sometimes should second guess their corporate clients).

77 Compare Griffith, Afterward and Comment: Towards an Ethical Duty to Market Investors, n 39 above, at 1232 (arguing that a lawyer should be responsible for seeking outcomes that 'are optimal from the perspective of the public generally, not merely from a particular client's point of view'), with ibid. at 1233 (admitting that his proposal 'seem[s] a bit abstract'). 
leaving shareholders of the Originator with huge losses as a result of contingent recourse that wipes out most of their equity. Because structured finance lawyers should have the right to help facilitate lawful structured finance transactions, the lawyer's actions should not be subject to criticism, nor should the lawyer be subject to liability. This assumes, of course, that the lawyer examined at least the portion of the transaction relating to the tasks he performed and did not encounter any warning signs ${ }^{78}$ (or, if the lawyer did encounter warning signs, that he investigated further as appropriate. ${ }^{79}$ ) Correlatively, if the lawyer encountered warning signs and did not investigate, the lawyer should be subject to criticism if not liability.

This framework similarly would apply if the structured finance lawyer acts negligently when helping to facilitate the structured finance transaction, simply by adding to the above analysis the applicable liability standard for negligence.

Consider also what may be the most difficult of cases: where the lawyer helps facilitate a structured finance transaction, knowing that the sole purpose of the transaction is to achieve off-balance-sheet accounting results for the Originator-thereby avoiding any adverse effect on the Originator's stock price from booking the transaction as a balance-sheet liability. If this constitutes knowledge of a violation of positive law, the lawyer should be subject to liability. There is nothing illegal, however, about an Originator engaging in a transaction to achieve accounting results that are permitted under GAAP. ${ }^{80}$ Indeed, companies routinely engage in transactions primarily, if not solely, to achieve accounting results that are permitted under GAAP, such as selling assets and using the proceeds to repay debt, thereby reducing leverage. ${ }^{81}$ Moreover, the fact that a company engages in such a transaction should not, in and of itself, constitute a warning sign if the company is advised by certified public accountants. A lawyer ought to be able to assume that such accountants will comply with GAAP $^{82}$ unless on notice otherwise. To the extent society deems it inappropriate for companies to engage in transactions whose sole purpose is to achieve off-balance-sheet accounting results under GAAP, the solution-assuming reputational cost is an insufficient deterrent-is either to make those engagements unlawful or to restrict what is permitted as off-balance-sheet accounting under GAAP and not to constrain lawyers from helping to facilitate lawful transactions.

78 For examples of what might constitute warning signs, see n 55-64 and accompanying text.

79 The Limits of Lawyering, $\mathrm{n} 1$ above, at 34 (discussing the appropriate scope of such an investigation).

80 In the US, for example, GAAP sets accounting standards officially recognized as authoritative by the Securities and Exchange Commission (SEC). See The Limits of Lawyering, $\mathrm{n} 1$ above, at 20.

81 Linda A. MacDonald, Principles-Based Approach to Standard Setting, The FASB Report, 27 November 2002, available at http:// www.fasb.org/project/principles-based_approach.shtml.

82 Cf Restatement (Third) of the Law Governing Lawyers §94(2)(b) (2000) (stating that a lawyer should not be disciplined 'when the lawyer reasonably believes... that the client can assert a nonfrivolous argument that the client's conduct will not constitute a crime or fraud'). 
The United States, at least, may be heading in this very direction. On 15 June 2005, the SEC staff released its report on off-balance-sheet transactions, as required by the Sarbanes-Oxley Act. ${ }^{83}$ This report focused, among other things, on whether financial statements of Originators transparently reflect the economics of off-balance-sheet arrangements. ${ }^{84}$ The report recommended that 'transactions and transaction structures primarily motivated by accounting and reporting concerns, rather than economics' be discouraged through a combination of changes to accounting standards by the Financial Accounting Standards Board ${ }^{85}$ and greater awareness by participants in the financial reporting process. ${ }^{86}$ In this latter context, the report suggested that technical compliance with financial reporting requirements would be unsatisfactory when the Originator's investors are nonetheless misled or have insufficient information to understand the issuer's activities. ${ }^{87}$ After indicating that nuanced approaches to accounting disclosure may be ineffective because 'financial structures are virtually limitless and continue to evolve at a rapid pace, ${ }^{88}$ the report suggested that improvement in transparency and comparability across [Originators] can perhaps most directly and quickly be accomplished by eliminating the use of such structured transactions' whose sole (or perhaps even primary) purpose is motivated by accounting treatment. ${ }^{89}$

That SEC staff report, although not yet positive law and indeed not even formally approved by the SEC's Commissioners, appears to represent a shift in the normative view of accounting-motivated structured finance. Accordingly, that a future structured finance transaction is undertaken in the United States solely or primarily for accounting goals might well raise a warning sign. ${ }^{90}$ Structured finance counsel therefore should examine the transaction closely before engaging in the representation.

To understand how such an examination might proceed, consider a simple example. A lawyer asked to represent a client in selling the client's warehouse learns that the client's sole purpose for selling the warehouse is to use the sale proceeds to pay down debt and reduce balance-sheet leverage. Although this transaction is 'primarily motivated by accounting and reporting concerns,' few would argue it is wrongful. Sales of tangible property are commonplace, and relatively few burdens associated with such sales are typically retained by sellers.

Now vary the facts slightly. Assume, first, that the lawyer is asked to represent the client in selling the client's financial assets to an SPV, which in turn sells securities to investors to finance the assets' purchase. So far, this is a classic structured finance

83 Report and Recommendations Pursuant to Section 401(c) of the Sarbanes-Oxley Act of 2002 On Arrangements with Off-BalanceSheet Implications, Special Purpose Entities, and Transparency of Filings by Issuers, available at http://www.sec.gov/news/studies/ soxoffbalancerpt.pdf.

84 Ibid.

85 This Board, commonly referred to as FASB, is delegated power by the SEC to promulgate US GAAP.

86 Report and Recommendations Pursuant to Section 401(c) of the Sarbanes-Oxley Act of 2002, n 84 above, at 3.

87 Ibid.

88 Ibid. at 46 .

89 Ibid.

90 n 59 and 69 above and accompanying text. 
transaction, by itself not wrongful. Next assume that the lawyer learns that the client's sole purpose for engaging in this transaction is, as in the 'simple example' above, to use the sale proceeds to pay down debt and reduce balance-sheet leverage. Being 'primarily motivated by accounting and reporting concerns,' this revelation raises a warning sign.

Under this article's framework, the lawyer should not represent the client without favourably resolving this warning sign. One way to accomplish that is to ascertain whether the transaction is misleading and harmful to the client's investors. If it is not, that should be sufficient to favourably resolve this warning sign. In the transaction described above, for example, the lawyer should examine whether the benefits and burdens associated with the transferred financial assets have been shifted to the SPV and its investors in a manner consistent with a sale of those assets. This is much the same analysis that structured finance lawyers must make in order to opine that the transfer of financial assets constitutes a true sale for bankruptcy purposes. ${ }^{91}$ The lawyer also presumably should take into account whether any burdens not so shifted-especially to the extent they constitute contingent liabilities-have been adequately disclosed to the client's investors. To the extent these benefits and burdens have been shifted in a manner consistent with a sale of financial assets and that any burdens not shifted have been adequately disclosed, that finding ought to be sufficient to dispel the warning sign. ${ }^{92}$

\section{Conclusions}

In otherwise lawful structured finance transactions, the Originator's managers-not structured finance counsel-should be responsible for ensuring that the Originator's investors are benefited, not harmed. The corporate governance system can nonetheless break down when, as in Enron, the structured finance transactions are so complex that few in management understand them and the managers touting those transactions are materially conflicted. The solution to that failure, however, lies in fixing corporate governance, not in lawyering per se. ${ }^{93}$

Structured finance lawyers should not, of course, help facilitate unlawful structured finance transactions. If a structured finance lawyer, for example, becomes aware of fraud, the lawyer cannot proceed and would have to report the fraud. Nonetheless, in-house counsel-not structured finance counsel-are better monitors of fraud, having more information about the Originator and its business goals and not normally being limited to working on discrete transactions. ${ }^{94}$

These conclusions, and this article's analysis, have focused on the public responsibility of structured finance lawyers, as transactional lawyers. The article's principles, however, should have equal application to assessing the public responsibility of transactional

91 Structured Finance, n 8 above, $\S \S 4: 1-4: 3$.

92 This is a normative analysis, which may or may not in fact satisfy the SEC staff.

93 n 49-50 above and accompanying text.

94 Indeed, many in-house legal staffs have attorneys specifically dedicated to corporate compliance with law. See In-House Counsel Must Lead Corporate Compliance Efforts, 11 Corp Legal Times, Issue 114, at 18 (May 2001). 
lawyers in other types of business transactions. Such lawyers generally should have the right, for example, to help facilitate lawful business transactions, meaning those in which neither the lawyer's actions nor the transaction is then illegal as a matter of positive law. Where the transaction is lawful as a matter of positive law but nonetheless may violate norms, the transactional lawyer may want to exercise special caution. In assessing whether a transaction is lawful, the lawyer should examine at least the portion of the transaction relating to the tasks performed. If in the course of that examination the lawyer spots warning signs, the lawyer should investigate further. What constitutes a warning sign should be decided by courts on a case-by-case basis because warning signs are more easily recognized than defined. In appropriate cases, the lawyer may want to obtain, as part of the due diligence investigation, an opinion from in-house counsel stating that the overall transaction does not violate law. Failure of in-house counsel to render such an opinion would signal a problem.

doi:10.1093/cmlj/kmlo04 